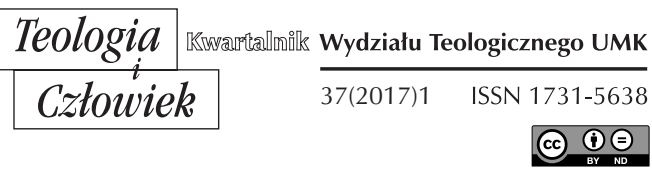

KS. JANUSZ GRĘŹLIKOWSKI*

WŁOCŁAWEK-WARSZAWA

\title{
KANONICZNE I DUSZPASTERSKIE ZNACZENIE INSTYTUCJI ZARĘCZYN
}

DOI: http://dx.doi.org/10.12775/TiCz.2017.007

Dzisiejszy klimat społeczno-kulturowy, obyczajowy i ekonomiczny wyzwala nie tylko szeroką dyskusję, ale powoduje również zamieszanie $\mathrm{w}$ problemach związanych $\mathrm{z}$ małżeństwem, a w jego kontekście $\mathrm{z}$ rodziną. Coraz bardziej dostrzega się i odczuwa osłabienie uwagi skoncentrowanej na godności, naturze oraz wartości małżeństwa i rodziny, bo jej miejsce zajmuje tematyka tożsamości płciowej, związków homoseksualnych, wartościowania praktyk seksualnych, aborcji, promowania wolnych związków i dostępu do możliwości uzyskania rozwodu czy też uzyskania orzeczenia nieważności małżeństwa kościelnego ${ }^{1}$. Coraz częściej kwestionowana jest

* Ks. Janusz Gręźlikowski - kapłan diecezji włocławskiej, dr hab. nauk prawnych w zakresie prawa kanonicznego; profesor UKSW w Warszawie, kierownik Katedry Historii Prawa Kanonicznego na Wydziale Prawa Kanonicznego UKSW; oficjał Sądu Biskupiego we Włocławku; wykładowca prawa kanonicznego w Wyższym Seminarium Duchownym we Włocławku i Wyższym Seminarium Duchownym Księży Misjonarzy Świętej Rodziny w Kazimierzu Biskupim (jgrezlikowski@diecezja.wloclawek.pl)

1 Por. Cz. Rychlicki, Małżeństwo przymierzem miłości i miłosierdzia, „Ius Matrimoniale" 26 (2015) 4 , s. 5. 
jedność i nierozerwalność małżeństwa, a nawet sens samej instytucji małżeńskiej, nie wspominając o powtarzających się coraz częściej próbach jej zniekształcania. Nie bez znaczenia pozostaje tutaj destrukcyjny wpływ idei szerzącej się sekularyzacji, konsumpcjonizmu oraz relatywizmu etycznego i poznawczego. Zamieszanie to, obok jeszcze innych przyczyn i zagrożeń życia małżeńskiego i rodzinnego, w tym nie doceniania i deprecjonowania wartości i znaczenia przygotowania do zawarcia małżeństwa, niewystarczającej znajomości narzeczonych przed zawarciem małżeństwa oraz niezrozumienia godności, celów, przymiotów i zadań małżeństwa, przyczynia się do dzisiejszego kryzysu małżeństwa i rodziny. Dał temu wyraz ostatni Synod Biskupów podejmujący niejako ofensywę od strony duszpasterskiej na rzecz ratowania małżeństwa i rodziny, jak też „towarzyszenia rodzinie na różnych etapach jej życia i rozwoju”2, co ukazuje i podsumowuje adhortacja posynodalna papieża Franciszka Amoris laetitia, która w rozdziale szóstym zwraca uwagę na odpowiednie przygotowanie do zawarcia sakramentu małżeństwa ${ }^{3}$.

W powyższym kontekście warto zwrócić uwagę na starą i dawną instytucję zaręczyn, która zawsze była i jest traktowana jako swego rodzaju ochrona przed pochopnym zawarciem małżeństwa oraz okres przygotowania do jego zawarcia, na co zwraca uwagę również papież Franciszek we wspomnianej adhotracji Amoris laetitia $a^{4}$ Zaręczyny „usilnie zaleca” Instrukcja Episkopatu Polski o przygotowaniu do zawarcia małżeństwa $w$ Kościele katolickim ${ }^{5}$. Zachęca ona do przywrócenia instytucji zaręczyn nowego blasku, wartości i znaczenia, jak też wskazuje na „głęboki sens duszpasterski i osobisty, służący lepszemu wzajemnemu poznaniu się nupturientów" ${ }^{\prime}$. Jaki zatem sens i walor kanoniczny posiada instytucja

2 Por. W. Góralski, Sprawiedliwość czy miłosierdzie. Problem Komunii świętej katolików rozwiedzionych i żyjacych w małżeństwie cywilnym, Płock 2016, s. 37-39; tenże, Adhortacja apostoska „Amoris laetitia” papieża Franciszka, Płock 2016, s. 5-6.

3 Ojciec Święty Franciszek, Posynodalna Adhortacja Apostolska „Amoris laetitia” o miłości w rodzinie (19.03.2016), Kraków 2016, nr 205-209.

${ }^{4}$ Ojciec Święty Franciszek, Posynodalna Adhortacja Apostolska „Amoris laetitia”, nr 205 i 209.

${ }^{5}$ Instrukcja Episkopatu Polski o przygotowaniu do zawarcia małżeństwa w Kościele katolickim, Kraków 1990, nr 32, s. 13. (cyt. dalej: IEP).

6 Tamże. 
zaręczyn? Jaką pełni rolę i znaczenie duszpasterskie dzisiaj? Czy może przyczynić się do lepszego przygotowania do małżeństwa i świadomego oraz bardziej odpowiedzialnego jego zawierania i traktowania? Jaką rolę i znaczenie posiada instytucja zaręczyn w prawie kanonicznym, czy istnieje w polskim prawie rodzinno-opiekuńczym lub cywilnym? Opracowanie pragnie odpowiedzieć na powyższe pytania oraz zamierza przybliżyć najważniejsze kwestie kanoniczno-duszpasterskie odnoszące się do instytucji zaręczyn.

\section{KULTUROWO-RELIGIJNE I PRAWNE KORZENIE ZARĘCZYN}

Zaręczyny (sponsolia), jako przyrzeczenie zawarcia w przyszłości małżeństwa, są instytucją o bardzo długiej tradycji, mającą korzenie w pierwotnych zwyczajach i normach prawnych. Początków zaręczyn można się doszukiwać już w czasach biblijnych, gdyż prawo Starego Testamentu znało instytucję zaręczyn ${ }^{7}$. Zaręczyny znane były i odbywały się też w starożytnej Grecji oraz Rzymie ${ }^{8}$. W celu zapewnienia trwałości podejmowanym zobowiązaniom podczas zaręczyn, rodzice zaręczających się podpisywali kontrakt, a narzeczona musiała zważać na swoje zachowanie i prowadzić się tak, jak przystało mężatce9.

W czasach, gdy prawo chrześcijańskie zaczęło się rozwijać, w Imperium Rzymskim zaręczyny były umową zawieraną między kobietą i mężczyzną, która miała na celu połączenie ich w przyszłości we wspólnotę małżeńską. Głównym elementem zaręczyn była oficjalna zgoda dwóch stron, ich forma zaś była dowolna. Zaręczyny były fakultatywne, a raz zawarte nie stanowiły pewności zaślubin. Każda ze stron w dowolnym momencie mogła zrezygnować z umowy zaręczynowej. Dopiero w III wieku daje się zauważyć tendencje dające instytucji zaręczyn większe znaczenie prawne, do czego przyczyniło się przyjęcie zaręczyn przez prawo kanoniczne ${ }^{10}$. W okresie

7 Por. Pwt 22, 23-24.

${ }^{8}$ L. Winniczuk, Ludzie, zwyczaje i obyczaje w starożytnej Grecji i Rzymie, Warszawa 1985, s. 121.

9 E. Banach, A. Banach, Słownik mody, Warszawa 1962, s. 163.

10 Por. W. Orawiecki, Zaręczyny w tradycji Kościoła powszechnego i współczesnym prawie kanonicznym, Wrocław 2008, s. 23-24. 
późnej republiki i pryncypatu, kiedy związki małżeńskie były w Rzymie ukształtowane najswobodniej, znaczenie prawne zaręczyn zaczęło zmniejszać się do tego stopnia, że każda ze stron mogła jednostronnie wycofać się ze złożonej wcześniej obietnicy ${ }^{11}$. Ta swoboda zrywania zaręczyn uległa pewnemu ograniczeniu w prawie poklasycznym, które na nowo umacniało instytucję zaręczyn poprzez wprowadzenie pewnego zadatku przy składaniu przyrzeczenia zaręczynowego. W momencie, gdy mężczyzna nie dotrzymywał obietnicy ów zadatek przepadał na rzecz kobiety. Natomiast przypadku, gdy to kobieta nie dotrzymywała obietnicy, to ona musiała zwrócić zadatek jednak w zwiększonym wymiarze, początkowo w poczwórnej wysokości, potem $\mathrm{w}$ podwójnej ${ }^{12}$. Obowiązki wynikające z umowy zaręczynowej, jak np. obowiązek wierności, traktowano pod wpływem doktryny chrześcijańskiej odnoszącej się do obowiązków małżeńskich ${ }^{13}$.

Prawo germańskie nadawało zaręczynom jeszcze większe znaczenie. Według tego prawa, zaręczyny były umową, która poprzez wykonanie, nadawała znaczenie prawne małżeństwu. Upraszczając, można powiedzieć, że Germanie do małżeństwa potrzebowali tylko zaręczyn i aktu seksualnego. Jeśli tylko takie dwa czynniki nastąpiły, nie należało składać kolejnego oświadczenia woli dotyczącego bezpośrednio aktu zawarcia małżeństwa. Co ciekawe, zaręczyny wyłączały możliwość zawarcia małżeństwa, nawet po ich zerwaniu, z krewnymi osoby narzeczonej aż do czwartego stopnia ${ }^{14}$.

Jeżeli chodzi o zaręczyny w kulturze i religijności polskiej, to zaręczyny, zwane także zrękowinami lub zmówinami, należą do najdawniejszych zwyczajów weselnych. Już w pierwotnym prawie polskim zaręczyny stanowiły wzajemne przyrzeczenie zawarcia małżeństwa przez narzeczonych w obecności świadków. Gwarancją dotrzymania umowy było podanie sobie rąk przez strony lub ich przedstawicieli i złożenie wadium. Dużą rolę w tych obrzędach i omawianiu wszystkich spraw związanych z zawarciem małżeństwa odgrywał swat. Zaręczyny można było zerwać

11 K. Koloński, Prawo rzymskie, Warszawa 2000, s. 229-230.

${ }^{12} \mathrm{H}$. Kapiszewski, Stosunki majątkowe między narzeczonymi w prawie rzymskim klasycznym, „Prawo Kanoniczne” 20 (1977) 3-4, s. 263-280.

13 Tamże, s. 282.

${ }^{14}$ S. Biskupski, Prawo małżeńskie Kościoła rzymskokatolickiego, t. I, Warszawa 1956, s. 79. 
za obopólną zgodą. Po zaręczynach młodzi stawali się narzeczonymi ${ }^{15}$. Po zaręczynach „dawano na zapowiedzi”, czyli oficjalnie podawano do publicznej wiadomości informację o zamiarze zawarcia małżeństwa. Zapowiedzi były czytane przez trzy kolejne niedziele w kościołach parafialnych obojga narzeczonych. Od umowy zawarcia małżeństwa i „dania na zapowiedzi” rozpoczynał się tak naprawdę okres narzeczeństwa, który obfitował w cały kompleks obrzędów, symbolicznych ceremonii, przygotowań do ślubu i wesela. Wśród rodów szlachecko-magnackich wstępne umowy zaręczynowe zawierano często w okresie, gdy młodzi tak naprawdę byli jeszcze dziećmi ${ }^{16}$.

Można powiedzieć, że zaręczyny w polskiej kulturze i religijności odgrywały duże znaczenie rozpoczynając cały ciąg obrzędów prowadzących do zawarcia małżeństwa. Historycy dopatrują się nawet w zaręczynach pierwotnej świeckiej formy zawarcia małżeństwa. Kościół aż do Soboru Trydenckiego uważał za ważnie zawarte małżeństwa zawierane bez udziału duchownych, jeśli tylko zachowany został tradycyjny rytuał ${ }^{17}$.

\section{POCZĄTKI I HISTORIA INSTYTUCJI ZARĘCZYN W PRAWIE KANONICZNYM}

Instytucja zaręczyn jako wprowadzająca lub zwiastująca bliskie zawarcie małżeństwa, która była obecna w prawie i zwyczajach żydowskich, w normach klasycznego prawa rzymskiego, jak i tego z epoki chrześcijańskiej oraz w prawie starogermańskim, została przyjęta przez praktykę Kościoła, zostając następnie opisaną w kościelnych normach prawnych, tak w wymiarze powszechnym, jak i partykularnym. Kościół przejął je już w "gotowej formie", kierując się względami duszpasterskimi pragnąc, aby instytucja zaręczyn stanowiła ważny czynnik religijnej formacji małżeńskiej, a także widząc w niej swego rodzaju ochronę przed pochopnym zawieraniem małżeństw. Zaręczyny nie były traktowane przez prawo

15 Por. A. Bruckner, Dzieje kultury polskiej, Kraków 1831, s. 73.

${ }^{16}$ Por. K. Kitowicz, Pamiętniki czyli historia polska, Warszawa 1971, s. 61-61;

B. Ogrodowska, Zwyczaje, obrzędy i tradycje w Polsce, Warszawa 2001, s. 152-154.

17 Z. Gloger, Rok polski w życiu, tradycji i pieśni, Warszawa 1900, s. 42-43; por. G. W. Dąbrowska, Leksykon: Taniec w polskiej tradycji, Warszawa 2005, s. 132. 
kanoniczne jako warunek konieczny zawarcia małżeństwa, ani ważność małżeństwa kościelnego nie była uzależniona od wcześniejszych zaręczyn, jednakże od samego początku akceptował je Kościół jako pozytywny i korzystny oraz ważny akt przygotowawczy do przyszłego sakramentu małżeństwa ${ }^{18}$. Jakkolwiek Kościół nie uzależniał małżeństwa od zaręczyn, to jednak przypisywał im wielkie znaczenie wychowawcze, bowiem przez zaręczyny narzeczeni mieli należycie poznać się i przygotować do sakramentu małżeństwa. Z tego względu Kościół nalegał, aby zawierano zaręczyny publicznie, wobec świadków, przez wręczenie pierścionka lub przez pocałunek, albo też przez ogłaszanie zaręczyn w kościele. Co więcej Kościół do zaręczyn zachęcał i nie ulega wątpliwości, że już w pierwszych wiekach Kościoła błogosławiono związki zaręczynowe. W ten sposób pod wpływem chrześcijaństwa zaręczyny zyskały wielkie znaczenie, jakiego nigdy nie miały według prawa rzymskiego ${ }^{19}$.

W pierwszych wiekach Kościoła postrzeganie zaręczyn na Wschodzie i Zachodzie było takie samo, jednak w dalszym rozwoju chrześcijaństwa zarysowuje się coraz większa różnica co do rozumienia i traktowania jej instytucji w dyscyplinie Kościoła wschodniego i zachodniego ${ }^{20} . \mathrm{Na}$ Zachodzie nigdy nie przywiązywano do zaręczyn tak daleko sięgających skutków, a w szczególności nie przypisywano im znaczenia prawnego. W przeciwieństwie do prawa rzymskiego, zaręczyny w Kościele Zachodnim były umową przez wykonanie której małżeństwo zyskiwało swoje prawne istnienie. Zaręczyny nie były jednak małżeństwem i zawsze tak je traktowano. W Kościele Wschodnim instytucja zaręczyn z czasem zaczęła rozwijać się i przybierać swoiste cechy, na co przede wszystkim miało wpływ cywilne prawo bizantyjskie. Ich charakterystyczną cechą było zawieranie zaręczyn $\mathrm{z}$ błogosławieństwem kapłańskim ${ }^{21}$. Ponadto stanowiły one przeszkodę rozrywającą do zawarcia małżeństwa $\mathrm{z}$ inną osobą. Można było je unieważnić jedynie według zasad stosowanych przy rozwiązywaniu małżeństwa. W Kościele Zachodnim zaręczynom nigdy

${ }_{18}$ Por. W. Orawiecki, Zaręczyny w tradycji Kościoła powszechnego i współczesnym prawie kanonicznym, s. 42.

19 M. Sitarz, Słownik prawa kanonicznego, Warszawa 2014, s. 187.

20 M. Żurowski, Prawo małżeńskie Kościoła katolickiego, Warszawa 1971, s. 94.

${ }_{21}$ T. Gromnicki, Forma zawierania zaręczyn i małżeństwa według dekretu „Ne temere”, Kraków 1910, s. 7. 
nie przypisywano tak daleko sięgających skutków prawnych, chociaż niekiedy i tutaj błogosławiono zaręczyny. Zasadniczo Kościół Zachodni do ważności zaręczyn wymagał tylko wzajemnego przyrzeczenia zawarcia małżeństwa $\mathrm{w}$ przyszłości ${ }^{22}$.

Nad sprawą jednolitej i obowiązkowej w całym Kościele formy zaręczyn obradował Sobór Trydencki, jednak nie podjął w tej sprawie żadnej uchwały ${ }^{23}$. Kiedy w 1573 r. wniesiono do Kongregacji Soborowej zapytanie, czy formę przepisaną przez Sobór dla małżeństw należy stosować również i do zaręczyn, Kongregacja odpowiedziała, iż Sobór wydał uchwałę dotyczącą tylko małżeństw, natomiast co do zaręczyn obowiązuje dotychczasowe prawo. Jednakże ta sama Kongregacja godziła się na wydawanie przez poszczególnych biskupów norm partykularnych określających sposób i formę zawierania zaręczyn (np. w sposób publiczny, przed proboszczem). Nigdy jednak Stolica Apostolska nie zdecydowała się na jakąś wiążącą formę zaręczyn, która by odpowiadała ustawodawstwu kościelnemu ${ }^{24}$. Można powiedzieć, że prawo Kościoła katolickiego, aż do początku XX wieku, nie znało żadnej obowiązkowej formy zawarcia zaręczyn. Dopiero dekret Kongregacji Soboru Ne temere z dnia 2 sierpnia 1907 r., wydany z polecenia i za aprobatą papieża Pius X, ustalił dla całego Kościoła określoną formę zaręczyn, a mianowicie wskazał, że do ważności powinny być zawarte i sporządzone na piśmie i podpisane przez narzeczonych, jak też wskazał na umowny i fakultatywny ich charakter ${ }^{25}$.

Kodeks Prawa Kanonicznego z 1917 r. utrzymał dotychczasowy umowny charakter zaręczyn, zasadę ich fakultatywności i określoną ich

22 Tamże, s. 8.

${ }^{23} \mathrm{~B}$. Ojetti, In ius antepianum et pianum ex decreto „Ne temere”, Romae 1908, s. 65.

${ }^{24}$ Por. J. Roth, Forma zaręczyn i małżeństwa w prawie katolickim kościelnym, Kraków 1908, s. 7-8.

${ }^{25}$ Dekret stwierdzał: „Te tylko zaręczyny są ważne i wywołują skutki kanoniczne, które zawarto na piśmie podpisanym przez strony, albo przez plebana lub ordynariusza albo przynajmniej dwóch świadków. Jeżeli obie strony lub jedna z nich pisać nie umieją, należy to w tym piśmie zaznaczyć i dodać jeszcze jednego świadka, który wraz z plebanem lub ordynariuszem, albo z dwoma świadkami, o których wyżej powiedziano, pismo to podpisze". W. Abraham, Forma zawarcia zaręczyn i małżeństwa w najnowszym ustawodawstwie kościelnym, Lwów 193, s. 39-40. 
formę prawną. Główna różnica między prawem przedkodeksowym, a prawem kodeksowym z 1917 r. zasadzała się na innych skutkach prawnych, płynących z zawarcia małżeństwa. Aby zaręczyny były ważne wymagano, ażeby sporządzone były na piśmie, opatrzonym datą i podpisem ${ }^{26}$. Pismo musiało wyrażać jasno treść umowy zaręczynowej, to czy przyrzeczenie jest jednostronne czy dwustronne, bezwzględne czy warunkowe oraz określać przynajmniej w przybliżeniu czas zawarcia przyszłego małżeństwa. Osoby zawierające zaręczyny według tej formy musiały posiadać zdolność do podejmowania czynności prawnych i czynić to dobrowolnie. $\mathrm{Na}$ skutek ważnie zawartych zaręczyn powstawał obowiązek moralny, w sumieniu, zawarcia w swoim czasie małżeństwa. Z ważnie zawartych zaręczyn wypływał również obowiązek dochowania sobie wzajemnie wierności ${ }^{27}$. Umowę zaręczynową, jak każda umowę prywatną, można było rozwiązać za obopólna zgodą. Jeżeli umowa ta była jednostronna, wystarczyło odwołanie strony przyrzekającej. Zaręczyny zawarte $\mathrm{w}$ formie nie przepisanej przez prawo kodeksowe nie pociągały za sobą żadnych skutków prawnych na zewnątrz, jak również w wymiarze moralnym ${ }^{28}$.

Należy stwierdzić, że regulacje zawarte w Kodeksie Pio-Benedyktyńskim nie zmieniły wcale ani właściwego dotychczas prawu kanonicznemu pojęcia zaręczyn, ani ich charakteru, lecz przekształciły tę dotąd nieformalną czynność prawną w akt prawny uroczysty.

Prawo kościelne w Polsce znało zaręczyny przynajmniej od XIII wieku, kiedy to legat papieski Jakub na synodzie we Wrocławiu w $1248 \mathrm{r}$. zarządził, aby zaręczyny miały charakter religijny i odbywały się w obecności kapłana ${ }^{29}$. Najbardziej znanym polskiej historii przypadkiem zaręczyn, zwanych sponsolia pro futuro, był związek Jadwigi Andegaweńskiej z Wilhelmem Habsburgiem, który został zaaranżowany, gdy Jadwiga miała cztery lata, a Wilhelm osiem lat ${ }^{30}$.

${ }^{26}$ Por. kan. 1017 § 1 i 2 KPK z 1917 r.; Zob. T. Burgt, Tractatus de matriomonio, Utrechts 1908, s. 125.

${ }_{27}$ Por. kan. 1017 \$ KPK z 1917 r.; zob. S. Biskupski, Prawo małżeńskie Kościoła rzymskokatolickiego, s. 82-83.

${ }^{28}$ I. Grabowski, Prawo kanoniczne według nowego kodeksu, Lwów 1927, s. 403.

${ }_{29}$ J. Gręźlikowski, Pasterska troska Kościoła o małżeństwo i czynności poprzedzajace jego zawarcie w świetle Instrukcji Episkopatu z 1987 r., „Homo Dei” 61 (1992) 4, s. 6.

${ }^{30}$ E. Kamarad, Charakter prawny zaręczyn w prawie materialnym i kolizyjnym, 


\section{ZARĘCZYNY W OBOWIAZZUJĄCYCH NORMACH PRAWA KANONICZNEGO}

Normy prawne zawarte w Kodeksie Prawa Kanonicznego z 1917 r. znacząco i trwale wyznaczyły dyscyplinę Kościoła w zakresie znaczenia i pielęgnowania zaręczyn jako instytucji poprzedzającej zawarcie małżeństwa w Kościele katolickim, której przedmiotem było złożenie uroczystej obietnicy (przyrzeczenia) zawarcia małżeństwa z zachowaniem obowiązującej formy prawnej ${ }^{31}$. Obecnie obowiązujące przepisy kodeksowe wyraźnie określa, że zaręczyny regulowane są wyłącznie prawem partykularnym, czy lokalnym, ustanowionym przez Konferencję Episkopatu, z uwzględnieniem zwyczajów oraz prawa świeckiego. Prawodawca powtórzył poprzednią normę zakresie skutków zaręczyn. Stwierdził, że przyrzeczenie małżeństwa nie stanowi podstawy do wniesienia skargi, żądającej zawarcia małżeństwa. Przyznał jednak, że stronie przysługuje skarga o wynagrodzenie szkód, jeżeli z racji zerwania zaręczyn takowe po$w_{s t a ł y}{ }^{32}$. Norma kodeksowa nie przewiduje jednakowej formy zawierania zaręczyn w całym Kościele katolickim, lecz dotychczasowe uprawnienia powszechne ceduje na Kościoły partykularne, zwłaszcza co do określenia formy zaręczyn. Dlatego podmiotem ustanawiającym ewentualne normy prawne jest Konferencja Episkopatu, która powinna uwzględnić lokalne zwyczaje i normy prawa państwowego, jeśli w danej społeczności zostały określone i ustawowo przyjęte. Podyktowane to zostało tym, że prawodawca kościelny uważa i zakłada, iż prawodawca partykularny skuteczniej, precyzyjniej i szczegółowiej potrafi określić normy odnoszące się do zaręczyn w poszczególnych krajach, niż uczyniłby to prawodawca powszechny, co lepiej przyczyni się do dynamicznego i pożytecznego przygotowania pastoralnego nupturientów do zawarcia małżeństwa.

W związku z tym stosowne postanowienie w przedmiocie zaręczyn powzięła Konferencja Episkopatu Polski w Instrukcji o przygotowaniu

w: www.europeistyka.uj.edu.pl/documents/.../49b9263e-f263-43e0-a791-d93465483fe2 (dostęp 16.09.2016).

${ }^{31}$ E. Sztafrowski, Prawo kanoniczne w okresie odnowy soborowej, t. II, Warszawa 1979, s. 208.

${ }^{32}$ Kan. 1062 \& 1 i 2 KPK; Por. W. Góralski, Kościelne prawo małżeńskie, Warszawa 2006, s. 29-31. 
do zawarcia małżeństwa $w$ Kościele katolickim z dnia 5 września 1986 r. Biorąc pod uwagę aktualną sytuację wiernych oraz częsty brak wystarczającej znajomości przedślubnej nupturientów, Episkopat Polski postanowił nawiązać do dawnych zwyczajów i ożywić przygotowanie narzeczonych do małżeństwa poprzez odnowienie instytucji zaręczyn ${ }^{33}$. Stąd Instrukcja usilnie zaleca „by zaręczyny odbywały się przynajmniej sześć miesięcy przed ślubem. Obydwie najbliższe rodziny, tj. o ile to możliwe rodzice, rodzeństwo i dziadkowie, powinny spotkać się na skromnej uroczystości rodzinnej. Dobrze zorganizowana i przeżyta uroczystość ułatwi nawiązanie bliższych kontaktów obydwu rodzinom. Rodzice obydwu stron (a w ich braku opiekunowie z ramienia rodziny, np. dziadkowie lub ktoś z rodzeństwa rodziców względnie najstarszy brat czy siostra) są upoważnieni przez biskupa diecezjalnego (por. kan. 1168) do pobłogosławienia pierścionków zaręczynowych, które następnie wymieniają sobie oblubieńcy, oświadczając, że odtąd będą się uważać za narzeczonych i zamierzają się pobrać w ustalonym czasie, jeżeli przez wzajemne poznanie się, zgodnie dojdą do przekonania, że potrafią stworzyć dobrane i zgodne małżeństwo. Są bowiem świadomi, że dalsze losy ich przyszłego związku zależą w dużym stopniu od trafnego wzajemnego wyboru"34.

Instrukcja wskazuje również cele, jakim służy instytucja zaręczyn: lepsze wzajemne poznanie się stron, swoich charakterów, zalet, umiejętności, ale i obciążeń dziedzicznych, gdyby takie były, a nadto ewentualnych uzależnień i anomalii psychicznych ${ }^{35}$. Biskupi polscy widzą w zaręczynach głęboki sens duszpasterski i osobisty: poczucie moralnego związania się narzeczonych danym sobie przyrzeczeniom, mobilizację do wzajemnego odnoszenia się do siebie z szacunkiem ze względu na dobro przyszłego małżeństwa, bez korzystania z uprawnień, które przysługują wyłącznie małżonkom oraz możliwość lepszego przygotowania się do małżeństwa i podjęcia bardziej rozważnej decyzji ${ }^{36}$.

Zaręczyny zatem ze swoją dobrą, długoletnią tradycją, nadal winny być traktowane jako czas sprawdzenia się i wzajemnego poznawania

\footnotetext{
33 IEP, nr 30.

${ }^{34}$ Tamże, nr 32.

35 Tamże, nr 33.

36 Tamże, nr 34.
} 
się narzeczonych, wprowadzania drugiej strony do rodziny, jak też jako ubogacającym okresem przygotowania do małżeństwa.

\section{PRZEPISY O ZARĘCZYNACH W POLSKIM PRAWIE CYWILNYM}

Jak zaznaczono wcześniej, prawo kościelne w Polsce znało instytucję zaręczyn przynajmniej od połowy XIII wieku, kiedy to legat papieskie Jakub na synodzie odbytym we Wrocławiu w 1248 r. zalecił, aby w życiu duszpasterskim Kościoła w Polsce funkcjonowały zaręczyny i aby miały charakter religijny oraz odbywały się w obecności kapłana ${ }^{37}$. Andrzej Zamojski w swej próbie kodyfikacji prawa polskiego z $1778 \mathrm{r}$. wprowadził instytucję zaręczyn do prawodawstwa cywilnego określając, że „są one umową przez którą dwie strony przyrzekają sobie żyć w związku małżeńskim”38. Do warunków ważności zaręczyn zaliczył brak pokrewieństwa i odpowiedni wiek ${ }^{39}$. Prawo małżeńskie z 1836 r. znało tę instytucję prawną określając ją jako „wzajemne przyrzeczenie małżeństwa pomiędzy mężczyzną i kobietą bądź słowne, bądź złożone na piśmie, w akcie urzędowym lub prywatnym"40. Również austriacki kodeks cywilny obowiązujący na części terytorium Polski określał zaręczyny jako „przyrzeczenie poślubienia się". Niemiecki kodeks cywilny nie zawierał określenia zaręczyn, ale regulował instytucję zaręczyn ${ }^{41}$. Instytucja zaręczyn znana więc była $\mathrm{w}$ historii polskiego prawa rodzinnego, podobnie jak $\mathrm{w}$ regulacjach prawnych innych państw europejskich ${ }^{42}$.

37 J. Gręźlikowski, Pasterska troska Kościoła o małżeństwo i czynności poprzedzające jego zawarcie w świetle Instrukcji Episkopatu z 1987 r., s. 6.

38 Zbiór praw sądowych, przedruk, W. Dudkiewicz, Warszawa 1874, s. 128.

39 Tamże, s. 129.

40 A. Zielonecki, Zawarcie małżeństwa, Wrocław 1982, s. 11.

41 Tamże, s. 12.

${ }^{42}$ Zaręczyny, jako instytucja prawa cywilnego, doczekały się także regulacji w wielu nowożytnych ustawodawstwach państw europejskich. Cechą wspólną wszystkich tych regulacji był brak możliwości dochodzenia zawarcia małżeństwa na drodze sądowej. Natomiast możliwość zasądzenia odszkodowania w przypadku zerwania zaręczyn, gwarantowana przepisami niektórych państw, zależała od tego, czy zaręczyny zostały ogłoszone publicznie. Zob. E. Kamarad, Charakter prawny zaręczyn, s. 64. 
Polskie prawo cywilne z 1919 r. w art. 239 stwierdzało, że zaręczyny następują wtedy, kiedy nastąpiło przyrzeczenie małżeństwa pomiędzy mężczyzną a kobietą - słownie, na piśmie, w akcie urzędowym lub prywatnym. Zaręczyny nie były ważne, jeżeli pomiędzy osobami zaręczonymi z powodu przeszkód niedopuszczalnych, małżeństwo nie mogło zostać zawarte. Normy tego prawa zaznaczały, że nawet ważne zaręczyny nie dawały prawa żadnej ze stron, nawet na drodze sądowej, do zawarcia małżeństwa. Jednakże - jak zaznaczały - „osoba bez powodów słusznych niedotrzymania uczynionego na piśmie lub w obecności świadków, zobowiązana jest przeciwnej stronie wynagrodzić poniesione koszta i straty"43.

Instytucja zaręczyn występuje również $\mathrm{w}$ systemie prawa rodzinnego po 1945 r. W prawie rodzinnym Polski Ludowej, gdzie zmiany zostały wprowadzone jednym zdecydowanym cięciem poprzez dekret z 25 września 1945 r., który uznawał wyłącznie świecką formę zawarcia małżeństwa, co ciekawe, pozostawiono regulacje związane z zaręczynami. Zgodnie z tym aktem prawnym, zaręczyny powstawały przez wzajemne wyraźne przyrzeczenie małżeństwa ${ }^{44}$. Wniesienie powództwa o zawarcie małżeństwa $\mathrm{z}$ tytułu zaręczyn było niedopuszczalne, podobnie jak zastrzeżenie odszkodowania lub jakiejkolwiek korzyści na wypadek zerwania zaręczyn. Jednakże zerwanie zaręczyn bez słusznych powodów rodziło odpowiedzialność wobec drugiej strony, jej rodziców lub opiekunów za straty spowodowane uzasadnionymi przygotowaniami do zawarcia małżeństwa ${ }^{45}$.

Aktualnie obowiązujące przepisy polskiego prawa rodzinnego nie normują zaręczyn, co spowodowane jest najprawdopodobniej tym, że instytucja ta zdaniem ustawodawcy straciła na znaczeniu w porównaniu z dawnymi czasami i została potraktowana jako instytucja obyczajowa. Mimo to obietnica zawarcia małżeństwa złożona drugiej osobie może mieć swoje pewne konsekwencje prawne. Z punktu widzenia bowiem prawa cywilnego zaręczyny mogą być potraktowane jako umowa, na mocy której kobieta i mężczyzna uzgadniają między sobą, że w przy-

${ }^{43}$ Prawo cywilne obowiązujące na obszarze Kongresowego Królestwa Polskiego $z$ dodatkiem ustaw uzupetniających i orzecznictwa sądów kasacyjnych, Warszawa 1919, s. 155 .

${ }^{44}$ J. Witecki, Prawo rodzinne. Komentarz, Łódź 1989, s. 16.

45 Tamże, s. 17-18. 
szłości zawrą małżeństwo. Zgodnie z zasadą swobody umów, wyrażoną w art. 353,1 kodeksu cywilnego ${ }^{46}$, zawarcie takiej umowy jest dozwolone na zasadach ogólnych ${ }^{47}$. Ani treść, ani cel takiej umowy nie sprzeciwiają się bowiem naturze stosunku prawnego, jaki na jej mocy powstaje między stronami, ani przepisom kodeksu cywilnego, ani również zasadom współżycia społecznego. Biorąc jednak pod uwagę swobodę zawarcia związku małżeńskiego, która jest jedną z podstawowych zasad polskiego prawa małżeńskiego, mającą swoje oparcie nie tylko w brzmieniu przepisów kodeksu rodzinnego i opiekuńczego ${ }^{48}$, ale także konstytucji $\mathrm{RP}^{49}$ oraz w wiążących Polskę umowach międzynarodowych i prawie unijnym, zaręczyny muszą zostać potraktowane jako specyficzny typ umowy cywilnoprawnej ${ }^{50}$. I mimo, że obietnica zawarcia małżeństwa złożona drugiej osobie nie rodzi po stronie tej osoby żadnego zobowiązania do wstąpienia w związek małżeński, jednakże z jej złożenia mogą powstać pewne roszczenia majątkowe ${ }^{51}$.

\section{WSPÓŁCZESNE ZNACZENIE ZARĘCZYN}

Obserwując praktykę i życie duszpasterskie współcześnie, zwłaszcza przez ostatni czas, można zauważyć pewien zanik, czy wręcz upadek instytucji zaręczyn, aczkolwiek nie wszędzie jest on wyraźnie i jednoznacznie dostrzegalny. Być może przyczyną tego jest pewna zmiana obyczajowości i zachowań tradycjonalnych. Niektórzy sugerują, że zaręczyny w jakimś stopniu ograniczają osobistą wolność nupturientów, co może istotnie wpływać jako czynnik determinujący ich wolę przy podejmowaniu decyzji o wyrażeniu zgody małżeńskiej. Taki pogląd wydaje się mało uzasadniony i dyskusyjny. Instytucja zaręczyn bowiem, zarówno kościelna, jak i świecka, kanoniczna i cywilna, jest nadal bardzo wskazana i pożytecz-

46 Dz. U. z 1964 r., nr 16, poz. 93.

47 J. Ignatowicz, M. Nazar, Prawo rodzinne, Warszawa 2005, s. 83.

${ }^{48}$ Dz. U. z 1964 r., nr 9, poz. 59.

49 Art. 47, który stanowi, że „każdy ma prawo do [...] decydowania o swoim życiu osobistym", a więc także o zawarciu małżeństwa, Dz. U. z 1997 r., nr 78, poz. 483.

${ }^{50}$ E. Kamarad, Charakter prawny zaręczyn, s. 65.

51 Por. art. 410 i 415 k.c. 
na, szczególnie kiedy mass media i różne ośrodki wyjątkowo krzykliwie nagłaśniają błędne teorie dotyczące życia małżeńskiego i rodzinnego, jak również kiedy młodzi ludzie przejawiają wyjątkową lekkomyślność i nieodpowiedzialność podczas podejmowania decyzji o zawieraniu małżeństwa. Jakże często takie błędne decyzje pociągają za sobą brzemienne skutki i zobowiązania. Dlatego właśnie prawodawca kościelny scedował formę zawarcia zaręczyn i ożywienie znaczenia tej instytucji prawodawcom partykularnym, którzy skuteczniej i bardziej pragmatycznie potrafią dostosować normy prawne do zwyczajów i wielowiekowej tradycji danych społeczeństw.

Nie ulega wątpliwości, że okres znajomości przedślubnej i narzeczeństwa, jak i przygotowania do zawarcia małżeństwa, ma ważne znaczenie dla późniejszej wspólnoty małżeńskiej i rodzinnej. Kościół zawsze to podkreślał i przywiązywał wielką wagę do instytucji zaręczyn, jak i przygotowania do małżeństwa. Św. Jan Paweł II w swojej adhortacji Familiaris consortio wskazywał, że „bardziej niż kiedykolwiek, w naszych czasach konieczne jest przygotowanie młodych do małżeństwa i życia rodzinie" ${ }^{2}$. Na to samo zwraca uwagę papież Franciszek w adhortacji posynodalnej Amoris laetitia, gdzie mówiąc o prowadzeniu narzeczonych na drodze przygotowania do małżeństwa, wprost wskazuje na osoby zaręczone, aby „im pomóc w odkryciu wartości i bogactwa małżeństwa oraz dać możliwość rozpoznania niezgodności lub zagrożeń" ${ }^{53}$. Jednocześnie wskazuje, że „początkowe olśnienie zaręczonych prowadzi do usiłowania ukrycia lub relatywizowania wielu rzeczy, unikania niezgodności i trudności oraz przesuwania ich na przyszłość" ${ }^{54}$. Dlatego zachęca duszpasterzy, by „zaręczonych mobilizować, pobudzać i pomagać im, aby mogli wyrazić to, czego każdy oczekuje od ewentualnego małżeństwa, swego sposobu rozumienia, czym jest miłość i zaangażowanie, czego pragnie się od drugiej osoby, jaki typ wspólnego życia chce planować" 55 . Nadto wyjaśnia, że okres kiedy osoby są zaręczone winien poprzez ich rozmowy pomóc

${ }^{52}$ Jan Paweł II, Adhortacja apostolska o zadaniach rodziny chrześcijańskiej w świecie współczesnym Familiaris consortio, Watykan 1981, nr 66.

${ }^{53}$ Ojciec Święty Franciszek, Posynodalna Adhortacja Apostolska „Amoris laetitia” o miłości $w$ rodzinie, nr 205 i 209.

54 Tamże, nr 209.

55 Tamże. 
im dostrzec, „iż w rzeczywistości niewiele jest punktów wspólnych ich znajomości i że samo wzajemne zauroczenie nie wystarczy, aby utrzymać związek. Nic nie jest bardziej zmienne, niepewne i nieprzewidywalne dodaje papież Franciszek - niż pożądanie i nigdy nie należy zachęcać do decyzji o zawarciu małżeństwa, jeżeli nie doszło do pogłębienia innych motywacji, które dają tym zaręczonym realną szansę stabilności" ${ }^{36}$.

Jak z tego wynika, starodawna i tradycyjna instytucja zaręczyn, $\mathrm{w}$ ramach przygotowania do małżeństwa nie traci i dzisiaj swego znaczenia, sensu i wartości. Złożona bowiem rzeczywistość społeczna oraz wyzwania, przed jakimi stoi dziś małżeństwo i rodzina, wymagają zaangażowania całej wspólnoty chrześcijańskiej w przygotowaniu narzeczonych do małżeństwa oraz przygotowania programów przygotowania do małżeństwa, które byłyby prawdziwym doświadczeniem uczestnictwa w życiu kościelnym i pogłębiałby różne aspekty życia małżeńskiego i rodzinnego.

Ważne jest zatem prowadzenie narzeczonych na drodze przygotowania do małżeństwa, aby nauczyli się kochać tę konkretną osobę, z którą pragną dzielić całe życie. Czas bowiem refleksji i zastanowienia się, jakim jest okres od zaręczyn do zawarcia małżeństwa, pomaga nupturientom ostatecznie w podjęciu jak najbardziej właściwej i dobrej decyzji życiowej w zakresie podjęcia zobowiązań małżeńskich. Wzajemne poznanie i odczuwanie moralnego zobowiązania do zachowania wierności, okazywania troski i szacunku wobec siebie i planowanej wspólnoty życia zdecydowanie uczy pełniejszego zaufania sobie, jak również mobilizuje do szlachetności postaw nie tylko w okresie przygotowania do małżeństwa. Praktyka i dobre poznanie się przed zawarciem małżeństwa przenosi się na okres poślubny, co dobrze skutkuje i rokuje w dojrzałości postaw nupturientów na całe życie, w realizowaniu wspólnoty małżeńskiej, jak również w konsekwentnym realizowaniu obowiązków małżeńskich i w godnym korzystaniu $\mathrm{z}$ istotnych praw.

Wobec dzisiejszych zagrożeń i wyraźnego kryzysu małżeństwa i rodziny, wydaje się, że nie trzeba nikomu dzisiaj tłumaczyć i wyjaśniać znaczenia instytucji zaręczyn i roli przygotowania dalszego, bliższego i bezpośredniego do zawarcia małżeństwa. Dlatego warto i należy podejmować trud poważnego i rozważnego przygotowania osób zaręczonych

\footnotetext{
56 Tamże.
} 
i planujących zawrzeć małżeństwo w Kościele katolickim. Pomoże to uniknąć wielu nieszczęść w trybie zawierania małżeństwa, których przyczyną może być wielki pośpiech, brak odpowiedzialności i lekkomyślność, co pociąga za sobą nieobliczalne skutki. U podstaw niedojrzałej decyzji o zawarciu małżeństwa leży wiele istotnych przyczyn, a wśród nich m.in.: brak wystarczającej wzajemnej znajomości młodych przed ślubem, powolne przenikanie społeczeństwa przez mentalność rozwodową coraz powszechniej tolerowaną i usprawiedliwianą, podstępnie ukrywane, a nawet często tuszowane przez drugą stronę defekty osobowościowe lub nawet poważne anomalie psychoseksualne, które w okresie poślubnym objawiają się powodując konflikty, wzajemne posądzenie współmałżonka o umyślnie złą wolę, jak również starannie ukrywane w okresie przedślubnym nałogi i zakorzenione wady. W okresie narzeczeństwa po zaręczynach można dokładniej te negatywne postawy świadomie zaobserwować, by podjąć ostateczną decyzję w zakresie świadomego i dobrowolnego wyrażenia zobowiązującej zgody małżeńskiej ${ }^{57}$.

Należy też zauważyć, że zwyczaj zawierania zaręczyn w gronie rodzinnym prowadzi do głębszego zrozumienia wartości domowego Kościoła. To podkreśla typową i odpowiedzialną rolę rodziców i członków rodziny w procesie powstawania nowego związku, a także dowartościowuje się dziedzictwo jakie każdy wynosi z domu rodzinnego. Właśnie narzeczeństwo ma na celu lepsze wzajemne poznanie się narzeczonych. Chodzi głównie o wzajemne rozeznanie charakterów, zalet i umiejętności, a także ewentualnych wad, ukrytych defektów osobowościowych czy nawet celowo i świadomie skrywanych uzależnień i nałogów, np. pijaństwa, narkomanii, nieprawidłowej seksualności, niezdolności do podjęcia istotnych obowiązków małżeńskich z przyczyn natury psychicznej i innych ${ }^{58}$.

Zawierania zaręczyn nie narusza w żadnym wymiarze wolności wymaganej do zawarcia samego małżeństwa, dlatego mają głęboki sens osobisty i duszpasterski. Przez akt zawarcia zaręczyn narzeczeni przez dłuższy czas mogą się wzajemnie lepiej poznać, czuć się moralnie związani danym przyrzeczeniem, co zobowiązuje każdą stronę do wzajemnej

57 IEP, nr 29.

${ }^{58}$ Por. W. Góralski, G. Dzierżon, Niezdolność konsensualna do zawarcia małżeństwa kanonicznego. Kan. 1095, nn. 1-3 KPK, Warszawa 2001, s. 103-104. 
wierności względem siebie i nie pozwala na swobodne kontakty z osobami trzecimi. Wierność danemu przyrzeczeniu mobilizuje wzajemne odnoszenie się do siebie z szacunkiem, podyktowanym dobrem planowanego w niedalekiej przyszłości małżeństwa, bez korzystania z uprawnień, które z prawa Bożego przysługują wyłącznie małżonkom. Nawet dłuższy okres zaręczonych narzeczonych, zwłaszcza integralnie połączony z poważnym przygotowaniem do małżeństwa może się wydatnie przyczynić do dojrzałej, podejmowanej na całe życie decyzji. Taka wartość istotnie inspiruje do propagowania zawierania zaręczyn przez współczesne prawodawstwo Kościoła w Polsce. Znajduje to swoją realizację z normach i ustawodawstwie partykularnym, które $\mathrm{z}$ akceptacją odnosi się do pielęgnowania zdrowej tradycji i zwyczajów w tym zakresie. Podkreśla to wyraźnie II Synod Plenarny, zachęcając wiernych do korzystania z obrzędu zaręczyn, który jest wydrukowany w księdze błogosławieństw ${ }^{59}$. Rozpowszechnianie zwyczaju i praktyki zaręczyn w dużej mierze zależy od postawy osób duchownych, szczególnie duszpasterzy, którzy powinni zachęcać wiernych do ich zawierania przed wstąpieniem w związek małżeński, wyjaśniając przy tym ich chrześcijański sens.

Ukazana pokrótce instytucja zaręczyn zarówno od strony historyczno-prawnej, jak i obowiązującego prawa kanonicznego i prawa polskiego, przybliżyła znaczenie przyrzeczenia zawarcia małżeństwa szczególnie dla kanonicznego prawa małżeńskiego. Kościół przejął i wprowadził instytucję zaręczyn kierując się względami duszpasterskimi, dostrzegając w niej czynnik religijnej formacji, przygotowania do zawarcia małżeństwa, jak też swego rodzaju ochronę przed pochopnym zawieraniem małżeństwa sakramentalnego. Zaręczyny nie były jednak nigdy traktowane jako warunek konieczny zawarcia małżeństwa, ani ważność małżeństwa nie była uzależniona od wcześniejszych zaręczyn. Tak było dawniej i jest obecnie.

Pod wpływem Kościoła zaręczyny otrzymały bardziej uroczysty charakter. Co więcej Kościół wskazał do ważności zaręczyn określoną

${ }^{59}$ II Synod Plenarny (1991-1999), Poznań 2001, statut 129, s. 181. 
ich formę oraz umowny i fakultatywny ich charakter, mający pozytywny i ważny wpływ na przygotowanie do sakramentu małżeństwa. Regulacje zawarte w Kodeksie Prawa Kanonicznego z 1917 r. do ważności zaręczyn wymagały, aby były sporządzone na piśmie, opatrzonym datą i podpisem. Na skutek ważnie zawartych zaręczyn powstawał obowiązek moralny zawarcia w swoim czasie małżeństwa. Nie można jednak było obowiązku tego dochodzić na drodze sądowej, jednakże przysługiwało prawo dochodzenia na drodze sądowej strat, jakie poniosła strona na wypadek niesłusznego zerwania umowy zaręczynowej.

Obecnie obowiązujące ustawodawstwo kościelne nie reguluje formy zaręczyn, nakazując stosowne regulacje ustawodawcy partykularnemu, a mianowicie Konferencji Episkopatu, jednoczenie wskazując na ważność i znaczenie instytucji zaręczyn dla przygotowania do małżeństwa. Prawodawca stwierdził też, że przyrzeczenie małżeństwa nie stanowi podstawy do wniesienia skargi, żądającej zawarcia małżeństwa. Przyznał jednak, że stronie przysługuje skarga o wynagrodzenie szkód, jeżeli z racji zerwania zaręczyn takowe powstały. Nie przewiduje się również jednakowej formy zawierania zaręczyn w całym Kościele katolickim, lecz dotychczasowe uprawnienia powszechne ceduje się na Kościoły partykularne. Dlatego podmiotem ustanawiającym ewentualne normy prawne jest Konferencja Episkopatu, która powinna uwzględnić lokalne zwyczaje i normy prawa państwowego, jeśli w danej społeczności zostały określone i ustawowo przyjęte. Normy takie i zalecenia wydała Konferencja Episkopatu Polski $\mathrm{w}$ Instrukcji o przygotowaniu do zawarcia małżeństwa w Kościele katolickim z dnia 5 września 1986 r. Rola i znaczenie instytucji zaręczyn bardzo mocno została zaakcentowała przez papieża Franciszka w adhortacji Amoris laetitia, co stanowi wyzwanie dla duszpasterstwa.

Streszczenie. Kształtujące się od początków kościelne prawo małżeńskie przejęło instytucję zaręczyn z prawa rzymskiego, określając ją w kościelnych normach prawnych, tak w wymiarze powszechnym, jak i partykularnym. Kościół przejął i wprowadził do prawa kościelnego instytucję zaręczyn kierując się względami duszpasterskimi, dostrzegając w niej czynnik religijnej formacji oraz przygotowania do zawarcia małżeństwa, jak też swego rodzaju ochronę przed pochopnym zawieraniem małżeństwa. Zaręczyny nie były jednak nigdy traktowane jako warunek konieczny zawarcia małżeństwa, ani ważność małżeństwa nie była uzależniona od wcześniejszych zaręczyn. Tak było dawniej i jest obecnie. 
Obowiązujące ustawodawstwo kościelne wskazuje na ważność i znaczenie instytucji zaręczyn dla przygotowania do małżeństwa, nie reguluje jednak formy zaręczyn, nakazując stosowne regulacje ustawodawcy partykularnemu. Podmiotem ustanawiającym normy prawne w tym zakresie jest Konferencja Episkopatu, która powinna uwzględnić lokalne zwyczaje i normy prawa państwowego, jeśli w danej społeczności zostały określone i ustawowo przyjęte. Normy takie i zalecenia wydała Konferencja Episkopatu Polski w Instrukcji o przygotowaniu do zawarcia małżeństwa w Kościele katolickim dnia 5 września 1986 r. Rola i znaczenie instytucji zaręczyn bardzo mocno została zaakcentowała przez papieża Franciszka w adhortacji Amoris laetitia.

Słowa kluczowe: kanoniczne prawo małżeńskie; zaręczyny; przygotowanie do zawarcia małżeństwa; małżeństwo i rodzina.

Abstrat. Canonical and Pastoral Meaning of the Engagement. Emerging from the beginnings of the church marriage law took over the institution of engagement with the Roman law, describing it in church legal standards, both in terms of the universal and the particular. The church took over and brought to church law institution of engagement on grounds of pastoral, seeing in it a factor of religious formation and preparation for marriage, as well as a kind of protection against the hasty conclusion of marriage. Engagement does not, however, were never treated as a precondition for marriage, nor the validity of the marriage was not dependent on previous engagement. That was then and is now.

Governing Law Church shows the importance and significance of institutions engagement for marriage preparation, however, does not regulate the form of engagement, ordering the relevant regulations of the legislator particular. The entity establishing legal standards in this regard is the Bishops' Conference, which should take into account local customs and norms of state law, if the community were identified and legally accepted. These standards and recommendations of the Polish Bishops' Conference has issued Instructions for preparing to marry in the Catholic Church on 5 September 1986. The role and importance of the institution engagement was strongly emphasized by Pope Francis in the exhortation Amoris laetitia.

Keywords: canon law marriage; engagement; preparation for marriage; marriage and family.

\section{BIBLIOGRAFIA}

\section{ŹRÓDŁA:}

Canones et Decreta Concilii Tridentini ex editione Romana A. MDCCCXXXIV. Repetiti. Accedunt S. Congr. Card. Conc. Trid. Interpretum Declarationes ac Resolutiones ex ipso 
resolutionum thesuaro Bullario Romano et Benedicti XIV. S.P. Operibus et Constitutiones Pontificiae Recentiores ad jus commune spectantes e bullario Romano selectae. Assumpto Socio Friderico Schulte J.U.D. Guestphalo edidit Aemilius Ludovicus Richter J.U.D. Et in Lit. Univ. Berol. Prof. Publ. Ord., Lipsiae 1853.

Codex Iuris Canonici. Auctoritatae Ioannis Pauli pp. II promulgatus. Kodeks Prawa kanonicznego. Przekład polski zatwierdzony przez Konferencję Episkopatu, Pallottinum, Poznań 1984.

Codex Iuris Canonici. Pii X Pontificis Maximi iussu digestus. Benedicti Papae XV auctoritate promulgatus, red. P. Gasparri, Romae 1934.

Instrukcja Episkopatu Polski o przygotowaniu do zawarcia małżeństwa w Kościele katolickim, Kraków 1990.

Jan Paweł II, Adhortacja apostolska o zadaniach rodziny chrześcijańskiej w świecie współczesnym Familiaris consortio (22.11.1981), Watykan 1981.

Kodeks cywilny, Dz. U. z 1964 r., nr 16, poz. 93.

Konstytucja Rzeczypospolitej Polskiej, Dz. U. z 1997 r., nr 78, poz. 483.

Ojciec Święty Franciszek, Posynodalna Adhortacja Apostolska „Amoris laetitia” o miłości w rodzinie (19.03.2016), Kraków 2016.

Prawo cywilne obowiązujace na obszarze Kongresowego Królestwa Polskiego z dodatkiem ustaw uzupełniających i orzecznictwa sądów kasacyjnych, Warszawa 1919.

Zbiór praw sądowych, przedruk, W. Dudkiewicz, Warszawa 1874.

II Synod Plenarny (1991-1999), Pallottinum, Poznań 2001.

\section{LITERATURA:}

Abraham W., Forma zawarcia zaręczyn i małżeństwa w najnowszym ustawodawstwie kościelnym, Lwów 1936.

Banach E., Banach A., Słownik mody, Warszawa 1962.

Biskupski S., Prawo małżeńskie Kościoła rzymskokatolickiego, t. I, Warszawa 1956.

Bruckner A., Dzieje kultury polskiej, Kraków 1831.

Burgot T., Tractatus de matriomonio, Utrechts 1908.

Dąbrowska G. W., Leksykon: Taniec w polskiej tradycji, Warszawa 2005.

Gloger Z., Rok polski w życiu, tradycji i pieśni, Warszawa 1900.

Góralski W., Adhortacja apostoska „Amoris laetitia” papieża Franciszka, Płock 2016.

Góralski W., Dzierżon G., Niezdolność konsensualna do zawarcia małżeństwa kanonicznego. Kan. 1095, nn. 1-3 KPK, Warszawa 2001.

Góralski W., Kościelne prawo matżeńskie, Warszawa 2006.

Góralski W., Sprawiedliwość czy miłosierdzie. Problem Komunii świętej katolików rozwiedzionych i żyjących w małżeństwie cywilnym, Płock 2016.

Grabowski I., Prawo kanoniczne według nowego kodeksu, Lwów 1927.

Gręźlikowski J., Pasterska troska Kościoła o małżeństwo i czynności poprzedzające jego zawarcie w świetle Instrukcji Episkopatu z 1987 r., „Homo Dei” 61 (1992) 4, s. 3-16. 
Gromnicki T., Forma zawierania zaręczyn i małżeństwa według dekretu „Ne temere”, Kraków 1910.

Ignatowicz J., Nazar M., Prawo rodzinne, Warszawa 2005.

Kamarad E., Charakter prawny zaręczyn $w$ prawie materialnym i kolizyjnym, w: www. europeistyka.uj.edu.pl/documents/.../49b9263e-f263-43e0-a791-d93465483fe2 (dostęp 16.09.2016)

Kapiszewski H., Stosunki majątkowe między narzeczonymi w prawie rzymskim klasycznym, „Prawo Kanoniczne” 20 (1977) 3-4, s. 263-280.

Kitowicz K., Pamiętniki czyli historia polska, Warszawa 1971.

Koloński K., Prawo rzymskie, Warszawa 2000.

Krawiecki W., Zaręczyny w tradycji Kościoła powszechnego i współczesnym prawie kanonicznym, Wrocław 2008.

Ogrodowska B., Zwyczaje, obrzędy i tradycje w Polsce, Warszawa 2001.

Ojetti B., In ius antepianum et pianum ex decreto „Ne temere”, Romae 1908.

Roth J., Forma zaręczyn i małżeństwa w prawie katolickim kościelnym, Kraków 1908.

Rychlicki Cz., Małżeństwo przymierzem miłości i miłosierdzia, „Ius Matrimoniale” 26 (2015) 4, s. 4-16.

Sitarz M., Słownik prawa kanonicznego, Warszawa 2014.

Sztafrowski E., Prawo kanoniczne w okresie odnowy soborowej, t. II, Warszawa 1979.

Winniczuk L., Ludzie, zwyczaje i obyczaje w starożytnej Grecji i Rzymie, Warszawa 1985.

Witecki J., Prawo rodzinne. Komentarz, Łódź 1989.

Zielonecki A., Zawarcie małżeństwa, Wrocław 1982.

Żurowski M., Prawo małżeńskie Kościoła katolickiego, Warszawa 1971. 